\title{
EVALUATION OF ENHANCEMENT TECHNIQUES OF MAGNETIC ANOMALIES APPLIED TO STRUCTURAL INTERPRETATION OF THE ITAITUBA REGION, STATE OF PARÁ - BRAZIL
}

\author{
Alessandra de Barros e Silva Bongiolo ${ }^{1}$ and Francisco José Fonseca Ferreira ${ }^{2}$ \\ Recebido em 10 fevereiro, 2011 / Aceito em 23 março, 2012 \\ Received on February 10, 2011 / Accepted on March 23, 2012
}

\begin{abstract}
The purpose of this article is to describe the work carried out for evaluating enhancement techniques of magnetic anomalies applying the reductionto-the-pole method and its implications for structural interpretation of a region located in low magnetic latitude. With this objective, the answer given by several data enhancement methods with and without reduction-to-the-pole was analyzed. These methods were applied to synthetic prisms located at low magnetic latitudes similar to the area of analysis and the resulting anomalies were compared to those calculated at the magnetic pole. The synthetic data has been generated from a program that calculates the anomalies from prisms with arbitrary dimensions, susceptibilities and depths. The enhancement methods were also applied to magnetic data of rocks from the Amazon Basin and the Amazonian Craton, in the Itaituba region, Pará state, northern Brazil. The reduction-to-the-pole algorithm applied to synthetic data during this work improved the performance of the enhancement methods, once, after its application, the maximum amplitude of the transformed anomalies were positioned over the edges of the sources, facilitating magnetic-structural interpretation. Good correlation among magnetic lineaments - particularly those inferred by the recently proposed tilt derivative of the total horizontal gradient method - and the already interpreted geologic structures back up the reduction to the pole indicating it may be applied even when data is collected in low magnetic latitudes.
\end{abstract}

Keywords: aeromagnetometry, qualitative interpretation, enhancement methods, synthetic data, Amazon Basin.

RESUMO. 0 presente trabalho tem como objetivo avaliar técnicas de realce de anomalias magnéticas com aplicação do método de redução ao polo e suas implicações na interpretação estrutural de uma região localizada em baixas latitudes magnéticas. Para tal fim, foi analisada a resposta dos vários métodos de realce de anomalias magnéticas, aplicados sobre modelos sintéticos prismáticos gerados no ambiente geomagnético da área de estudo, e sobre estes dados reduzidos ao polo, os quais foram comparados com modelos elaborados no polo. Para criação dos dados sintéticos foi desenvolvido um programa que calcula as anomalias a partir de prismas com dimensões, susceptibilidades e profundidades arbitrárias. Os testes em dados reais foram aplicados em uma área que envolve rochas da Bacia do Amazonas e do Cráton Amazônico, na região de Itaituba-PA. Os resultados obtidos indicam que a técnica de redução ao polo utilizada neste trabalho é satisfatória, uma vez que os máximos das anomalias se posicionaram sobre as fontes, facilitando a interpretação magnética-estrutural. A boa correlação entre os lineamentos magnéticos obtidos - particularmente aqueles inferidos pelo método da inclinação do sinal analítico do gradiente horizontal total, recentemente proposto - e as estruturas geológicas já interpretadas para a área de estudo, apóia a aplicação da técnica de redução ao polo, mesmo sobre dados localizados em baixas latitudes magnéticas.

Palavras-chave: aeromagnetometria, interpretação qualitativa, métodos de realce, dados sintéticos, Bacia do Amazonas.

\footnotetext{
1 Laboratório de Pesquisas em Geofísica Aplicada, LPGA, Curso de pós-graduação em Geologia Exploratória, Departmento de Geologia, Universidade Federal do Paraná, Centro Politécnico, Jardim das Américas, Post Office box 19045, 81531-980 Curitiba, PR, Brazil. Phone: +55(41) 3361-3132 - E-mail: ale_barros@yahoo.com 2 Laboratório de Pesquisas em Geofísica Aplicada, LPGA, Curso de pós-graduação em Geologia, Departmento de Geologia, Universidade Federal do Paraná, Centro Politécnico, Jardim das Américas, Post Office box 19045, 81531-980 Curitiba, PR, Brazil. Phone: +55(41) 3361-3132 - E-mail: francisco.ferreira@ufpr.br
} 


\section{INTRODUCTION AND OBJECTIVES}

Magnetic interpretation is more complex than gravimetric interpretation, mainly due to the dipolar nature of the magnetic field, contrasting with the monopolar gravimetric field, in addition to the direction dependence for data acquisition and magnetization (induced and remanent). For this reason, the study of the magnetic signal behavior in synthetic models has acquired an extreme importance in assisting the interpretation of aeromagnetic data available in wide areas, in terms of the cartography of the geologic structures and contacts, form and source depths estimates, and preparation of the quantitative geophysical models.

The main objective of this article is to test the response of the magnetic signal given by synthetic models in areas near the magnetic equator (latitudes between $+20^{\circ}$ and $-20^{\circ}$, e.g. Li, 2008) and at the pole, to evaluate the performance of the reduction-tothe-pole (RTP) method in these areas, besides discussing the results of the application of several enhancement methods of magnetic anomalies, including the TAHG technique, recently developed by Ferreira et al. (2010). The magnetic responses of the enhancement methods - generated by synthetic models - were compared, based on the GRAV_MAG_PRISMA Program (Bongiolo et al., 2012), developed at the Laboratory for Research in Applied Geophysics at the Universidade Federal do Paraná (LPGA/UFPR). The several enhancement methods were also applied to real data from an area situated in the Itaituba region, near the Tapajós River, in the State of Pará, within the context of the Amazon Basin and its basement.

\section{METHODS}

Magnetic anomalies depend on the magnetization direction (induced and remanent) and the data acquisition direction (Blakely, 1996). Merely considering the induced magnetization, the reduction to the pole (RTP) technique makes it possible to have the anomalies positioned directly above the sources, minimizing the magnetic inclination effects. In this work, this technique is applied to synthetic models, inserted in areas of low magnetic latitudes, where the RTP technique is admittedly unstable, since the two parts - the real and the imaginary - both in the denominator of the RTP filter's equation, approach zero (e.g. Blakely, 1996; Li, 2008). For the application of the RTP filter, the Magmap module from the Oasis Montaj software was used (Geosoft, 2001), where the following parameters were requested: magnetic inclination and declination, besides a correction factor for the low latitude areas, which is related to the magnetic inclination complement for the studied area. For instance, if the magnetic inclination is $-18^{\circ}$, the correction factor to be used will be $-72^{\circ}$.
The research with synthetic models was carried out to evaluate the magnetic signal behavior and its limitations, according to the studied area location, which central point is at the geographic coordinates $4^{\circ} 00^{\prime} \mathrm{S}$ and $-55^{\circ} 15^{\prime} \mathrm{W}$, therefore very close to the magnetic equator (inclination $=+12^{\circ} 34^{\prime}$, declination $=-$ $13^{\circ} 18^{\prime}$ ), where the total field is almost essentially represented by its horizontal component.

Synthetic anomalies derived from magnetized bodies of known geometry are of great importance for evaluating the enhancement methods. Anomalies arising out of prismatic models are of particular interest, as a function of their similarity to the main geologic structures (Bhattacharyya, 1964; Talwani, 1965; Plouff, 1976; Singh \& Guptasarma, 2001).

With the intention of comparing the magnetic signal responses from synthetic models inserted in the studied area, reduced to the pole (RTP) and at the pole, several recently published anomaly enhancement methods were applied in order to delineate the limits of the sources to facilitate the magnetic-structural interpretation. The following enhancement techniques were used (Fig. 1): analytic signal amplitude (ASA - Nabighian, 1972, 1974; Roest et al., 1992), total horizontal derivative (THDR - Cordell \& Grauch, 1985), tilt angle (TDR - Miller \& Singh, 1994), total horizontal derivative of the tilt angle (TDR_THDR - VerduzCo et al., 2004) and tilt angle of the total horizontal derivative (TAHG - Ferreira et al., 2010).

As a means to evaluate the answer of the magnetic signal of 3-D synthetic models, from different locations of the Earth's surface, the program GRAV_MAG_PRISMA (Bongiolo et al., 2012) was developed, using MATLAB ${ }^{\circledR}$ language, based on Bhaskara Rao \& Ramesh Babu's proposal (1991), which setup is: inclination, declination and geomagnetic-field strength (IGRF), central coordinates $x, y$ and depths of the prisms' top ( $z$ ), magnetic susceptibility $(\kappa)$ and the bodies inclination in relation to North.

The GRAV_MAG_PRISMA program was used with the intention of discussing the magnetic responses from prisms located in different magnetic latitudes (studied area and at the pole), with the same dimensions, varying just the depth of the sources' top. Subsequently, the enhancement methods were applied in the sense of contributing to the evaluation of the signal attenuation and shift in reference to location of the causative sources.

Prisms were inserted in the geomagnetic pole, the ideal situation for interpretation, where the anomalies are located above sources, and in the geomagnetic environment of the studied area, which data was later reduced to the pole. Tests were carried out based on the 3-D models of Figure 2, with geometric and magnetic parameters listed in Tables 1 and 2, respectively. 


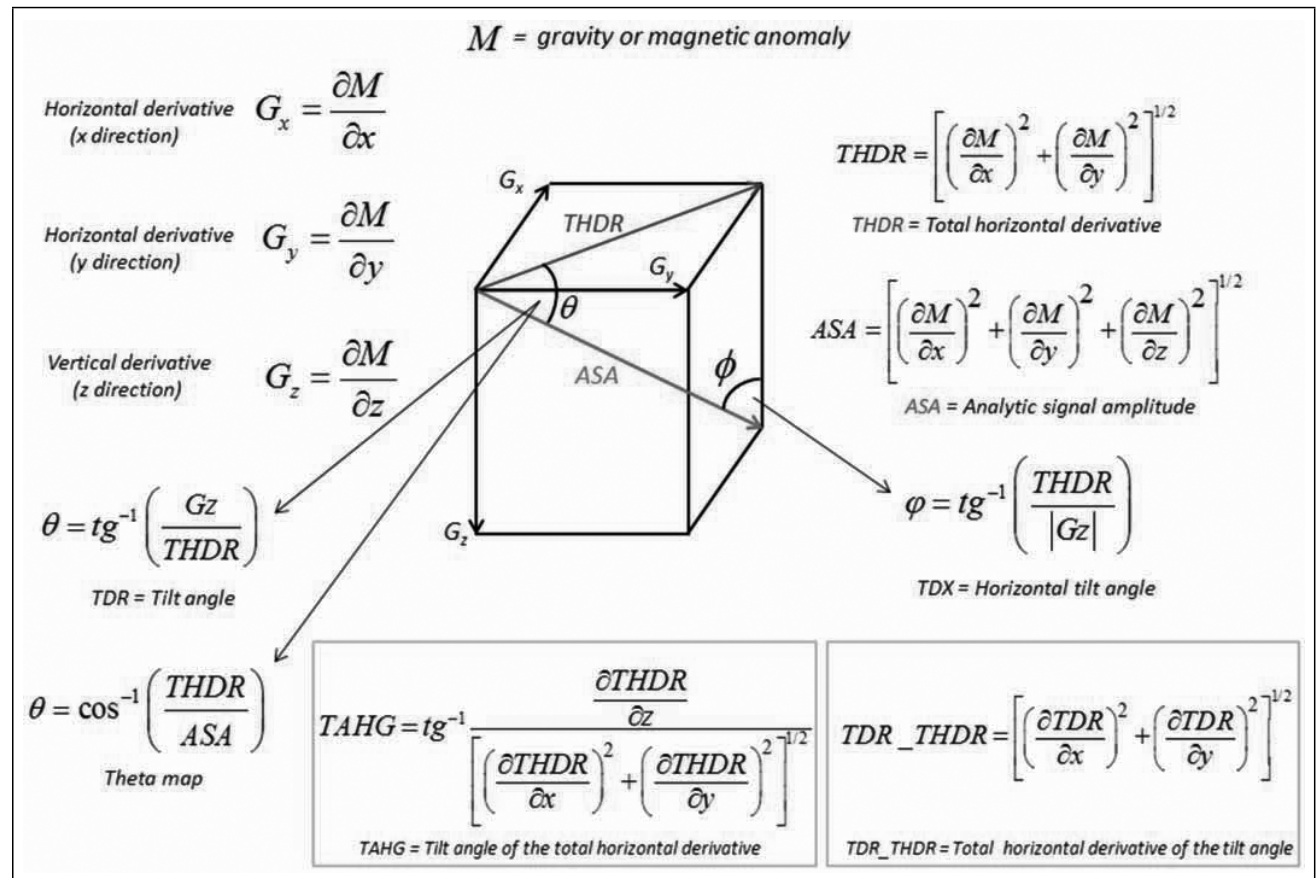

Figure 1 - Main enhancement techniques of gravimetric and magnetic anomalies. ASA (Nabighian 1972, 1974; Roest et al., 1992); THDR (Cordell \& Grauch, 1985); TDR (Miller \& Singh, 1994); TDR_THDR (Verduzco et al., 2004); Theta Map (Wijins et al., 2005); IGHT (Cooper and Cowan, 2006) and TDX (Ferreira et al., 2010).

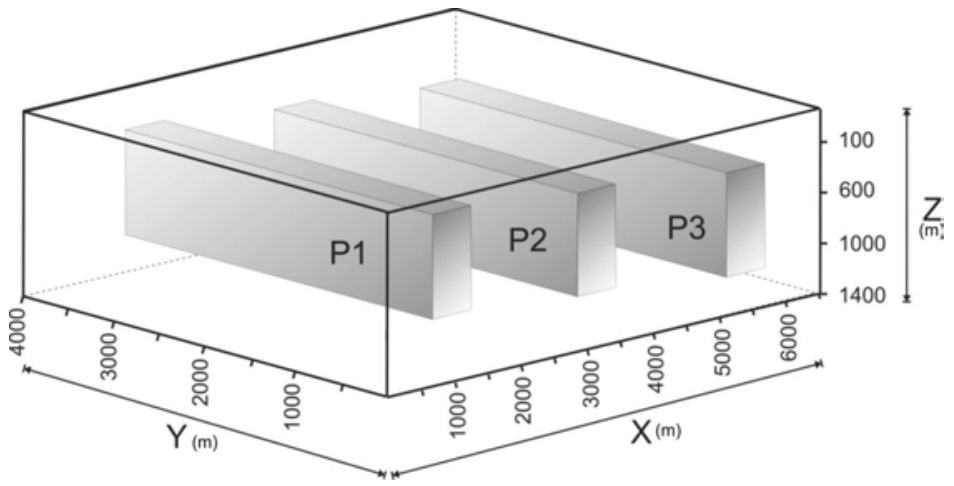

Figure 2 - Spatial distribution of the 3-D synthetic models in subsurface.

Table 1 - Geometric parameters of the models (Fig. 2).

\begin{tabular}{|c|c|c|c|}
\hline Location & Prism P1 & Prism P2 & Prism P3 \\
\hline X (m) & $500-1,000$ & $3,000-3,500$ & $5,500-6,000$ \\
X center & 750 & 3,250 & 5,550 \\
Y (m) & $500-3,500$ & $500-3,500$ & $500-3,500$ \\
Y center & 2,000 & 2,000 & 2,000 \\
Z (m) & $100-1,100$ & $200-1,200$ & $300-1,300$ \\
\hline
\end{tabular}

In accordance with data contained in Table 1, prisms exhibit the same dimensions, however depths to the top are different (P1 $=100 \mathrm{~m}, \mathrm{P} 2=200 \mathrm{~m}, \mathrm{P} 3=300 \mathrm{~m}$ ). According to Table 2, magnetization was considered induced $(\kappa=0.0276 \mathrm{SI}$ ) and the models were inserted in geomagnetic environments of the studied area (called Tapajós), and at the pole.

Table 2 - Magnetic parameters of the models (Fig. 2).

\begin{tabular}{|c|c|c|}
\hline Parameters & Tapajós & Pole \\
\hline Latitude & $04^{\circ} 00^{\prime} 00^{\prime \prime} \mathrm{S}$ & $85^{\circ} 00^{\prime} 00^{\prime \prime}$ \\
Longitude & $56^{\circ} 00^{\prime} 00^{\prime \prime} \mathrm{W}$ & $132^{\circ} 36^{\prime} 00^{\prime \prime}$ \\
Declination $\left(\mathrm{D}^{\circ}\right)$ & $-13^{\circ} 18^{\prime}$ & 0.0 \\
Inclination $\left(\mathrm{I}^{\circ}\right)$ & $+12^{\circ} 34^{\prime}$ & 90.0 \\
Intensity (nT) & 27,865 & 56,973 \\
$\mathrm{Ji}(\mathrm{A} / \mathrm{m})$ & 0.61 & 1.25 \\
\hline
\end{tabular}


Data generated by the GRAV_MAG_PRISMA program are supplied in ASCII format, and were imported to Oasis Montaj (Geosoft) platform. From that point, data were interpolated using the minimum curvature method (Briggs, 1974), to generate a regular grid, $20 \times 20 \mathrm{~m}$ spaced, resulting in the magnetic anomalies of Figure 3.

Depths of the sources were investigated through the radial power spectrum (Spector \& Grant, 1970), an important technique to discriminate signals from deep, intermediate and shallow sources and noises. The spectral analysis technique was applied to the synthetic and real data, which shows a graph with the wave number in the $x$ axis and the power spectrum logarithm in the $y$ axis, separating signals of different frequencies linked to depth statistical estimates.

\section{LOCATION AND GEOLOGY OF THE STUDIED AREA}

The studied area is located in the central-western portion of the State of Pará (Fig. 4), with approximately $27,000 \mathrm{~km}^{2}$, comprising the municipal districts of Itaituba, São Luiz, Aveiro, Trairão and Rurópolis. The area is limited by the geographic coordinates $3^{\circ} 20^{\prime}$ and $4^{\circ} 40^{\prime}$ of South latitude and $56^{\circ} 30^{\prime}$ and $54^{\circ} 50^{\prime}$ of West Iongitude. Access is by both roads BR-163 and Transamazonian or by boat, from Santarém, through the Tapajós River.

The lithostratigraphic units (Fig. 5) involve volcanic and volcanoclastics rocks of the Amazon Basin basement, in a cratogene volcano-plutonic association (Iriri Group, Salustiano and Buiuçu formations, undifferentiated granites of the $A$ and I types, Maloquinha Intrusive Suite). The basin's terrigenous sequences are represented by the Maecuru and Ererê formations (Urupadi Group), Curuá Group and by the siliciclastic and carbonate sequences of the Tapajós Group, represented by the Monte Alegre, Itaituba and Nova Olinda formations, according to the chronostratigraphic piling proposed by Cunha et al. (1994).

In the area, the Iriri Group, includes rocks with rhyolitic composition, besides volcanoclastics and pyroclastic breccias. Rocks with an intermediate to acid composition, such as andesites and tuffs were not found in the area under study (Santos, 2010). Geochronologic dating of these rocks (RADAMBRASIL, 1975) provide isochrons for this group varying between $1,645 \pm 83 \mathrm{Ma}$ and 1,693 $\pm 21 \mathrm{Ma}$. U/Pb age of 1,874 Ma was obtained for volcanics of Salustiano formation.

The Iriri Group is subdivided into the Salustiano Formations, where flows of felsic volcanic rocks prevail, represented by rhyolites, rhyodacites and dacites, and Buiuçu Formation, made up of old sedimentary covers with pebbles and clasts of volcanic and volcanoclastics rocks. In the remote sensors it is possible to observe a NNW-SSE orientation.

The majority of the undifferentiated Type I granites were individualized from the interpretation of remote sensor and aerogeophysical products (Faraco et al., 2004a,b; Rizzotto et al., 2004). These bodies predominantly present hilly relief, of the cupolatedtype, locally leveled, with average radiation in gamma-ray spectrometric maps of total count, and their predominant composition is of monzogranites with biotite, isotropic, heterogranular and coarse- to average-grained, besides syenogranites and granodiorites, with biotite, hornblende and hypersthene relicts and subordinate diopside.

The undifferentiated type A granites, are made up of leucosyenogranites and feldspar alkaline granites (mesoperthite granites), syeno and monzogranites with biotite and hastingsite heterogranular and porphyritic with rapakivi texture, besides quartz syenites with amphibole and biotite subordinately. The association of the identified lithotypes is similar to the granites of alkaline magmatic filiation or those of type A, typical of postorogenic or anorogenic extensional environment.

Granites of the Maloquinha Intrusive Suite are found as stocks and batholiths with circular, ellipsoidal to irregular forms, usually oriented in directions that vary from N-S to NW-SE. In the remote sensors they stand out by the rugged relief, with round hills, sometimes with flat tops, and by high radiation in gamma-ray spectrometric images. They are syenogranites and feldspar-alkaline granites, with monzogranites, quartz syenites and quartz monzonites subordinately. Biotite and amphibole are varietal minerals that help distinguish two different facies (Brito, 2000; Vasquez et al., 2000 a,b; Bahia \& Quadros, 2000).

In the basin's context, in the initial phase of the syneclise completion, there was an alternation of glacial and marine sediments, with ingressions from East to West, in onlap on the Purus Arch (Vasquez et al., 2000 a). A new transgression and regression cycle occurred in the Amazon Sedimentary Basin after the Caledonian orogeny, with marine and glacial sedimentation, which rocks were arranged in the Urupadi Group, subdivided into Maecuru and Ererê formations. They comprise neritic and deltaic sandstones and pelites (Maecuru Formation), of Early-Middle Devonian age, besides Middle-Devonian siltites, shales and neritic and deltaic sandstones of the Ererê Formation (Cunha et al., 1994). Intercalations of shales, siltites and fine sandstones, that underwent bioturbation, with worm tracks, make up the Jatapu Member of the Maecuru Formation, proposed by RADAMBRASIL (1975); according to Cunha et al. (1994) the Lontra Member is made up of thick intermediate- to coarse-grained sandstone 

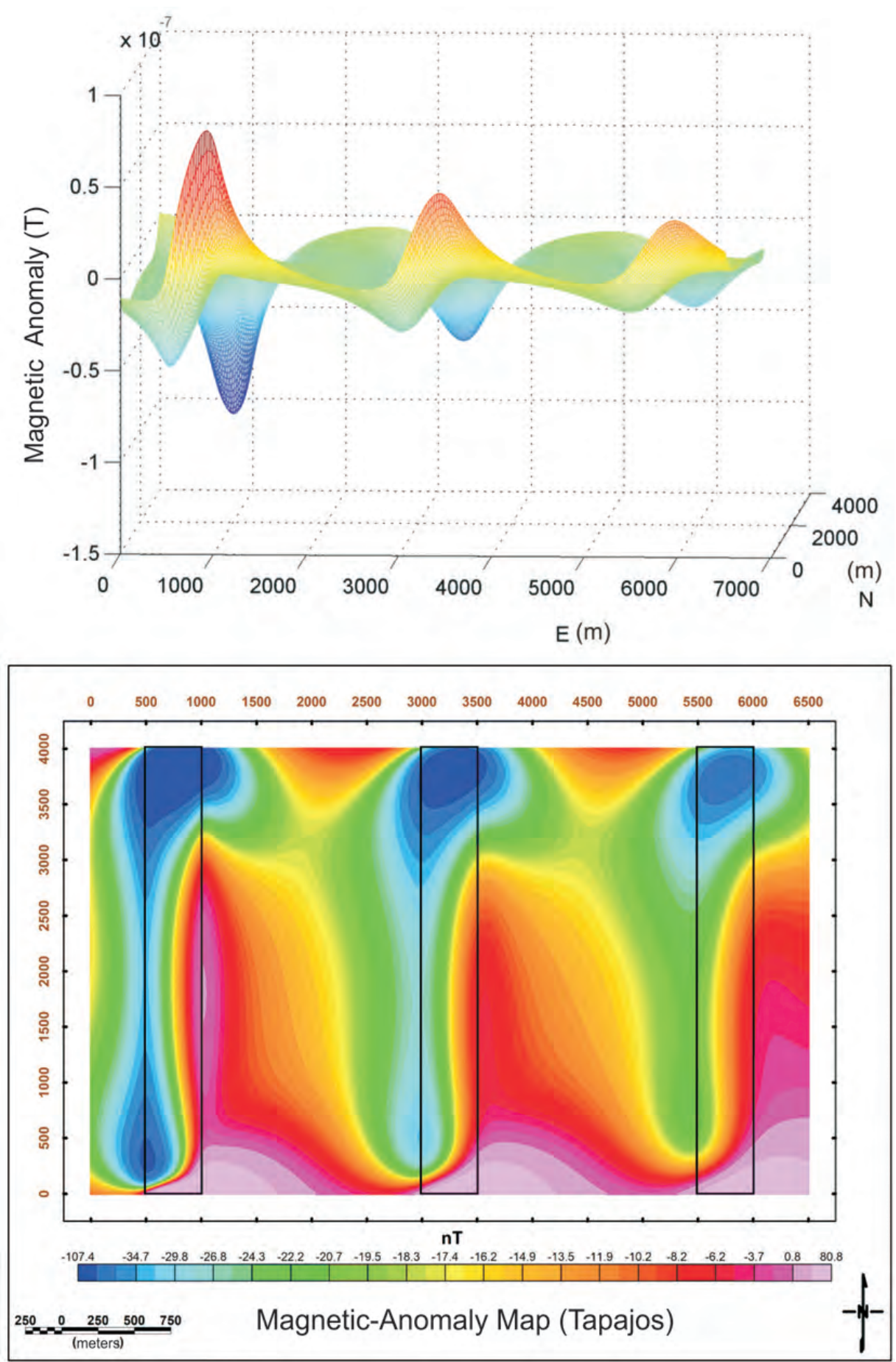

Figure 3 - Prims' magnetic anomalies (Fig. 2) generated using the GRAV_MAG_PRISMA program for the geomagnetic environment of the studied area (profile - top panel; plant - bottom panel).

benches, with cross-bedding, intercalated with shales and fine sandstones. Ererê Formation's basal portion shows dark gray shales, with sandstone intercalations that become more abun- dant towards the top. The fossil assemblage is represented by trilobites, brachiopods, spores, chitinozoans, scolecodonts and acritarches (RADAMBRASIL, 1975). 


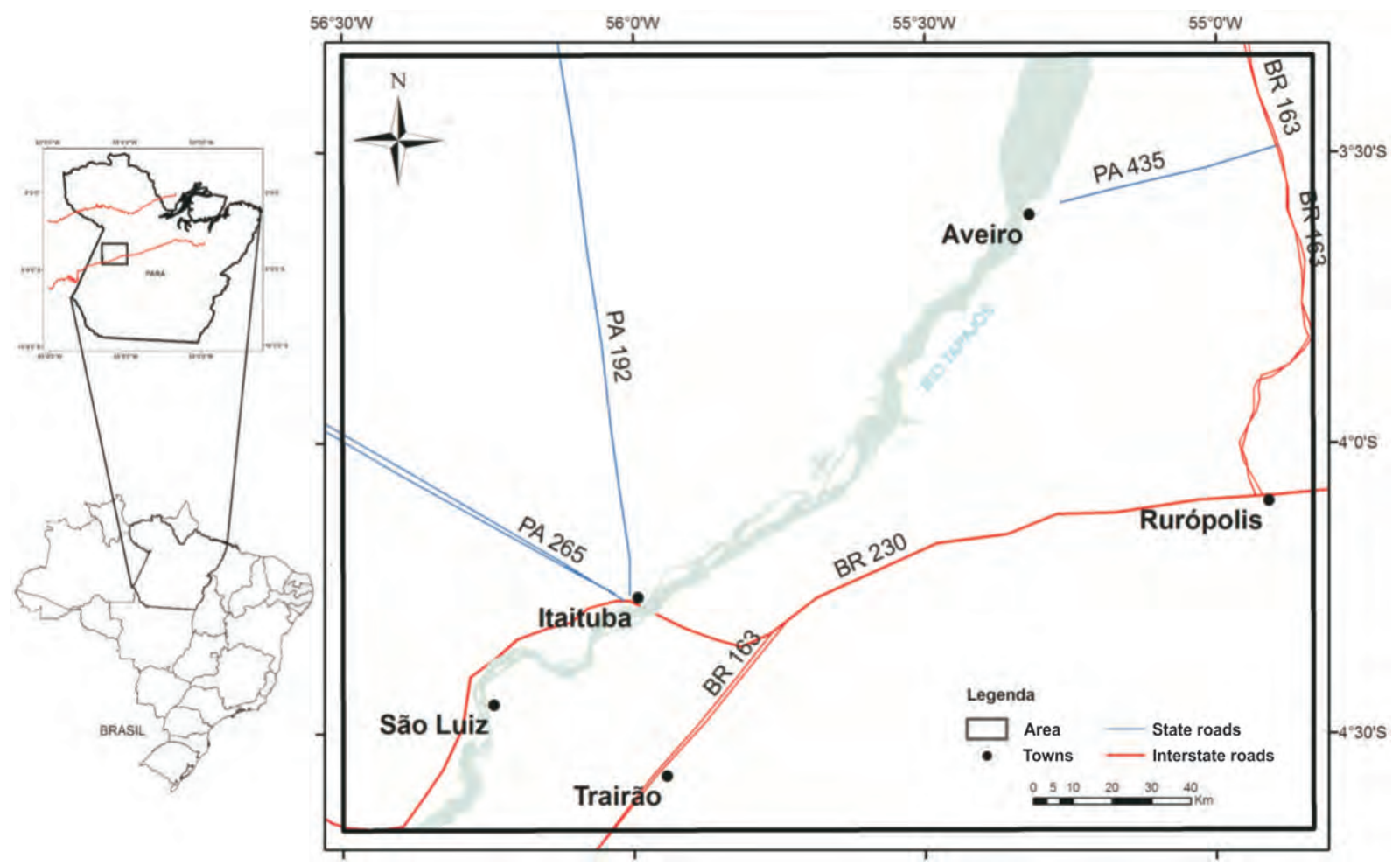

Figure 4 - Map with location of the studied area.

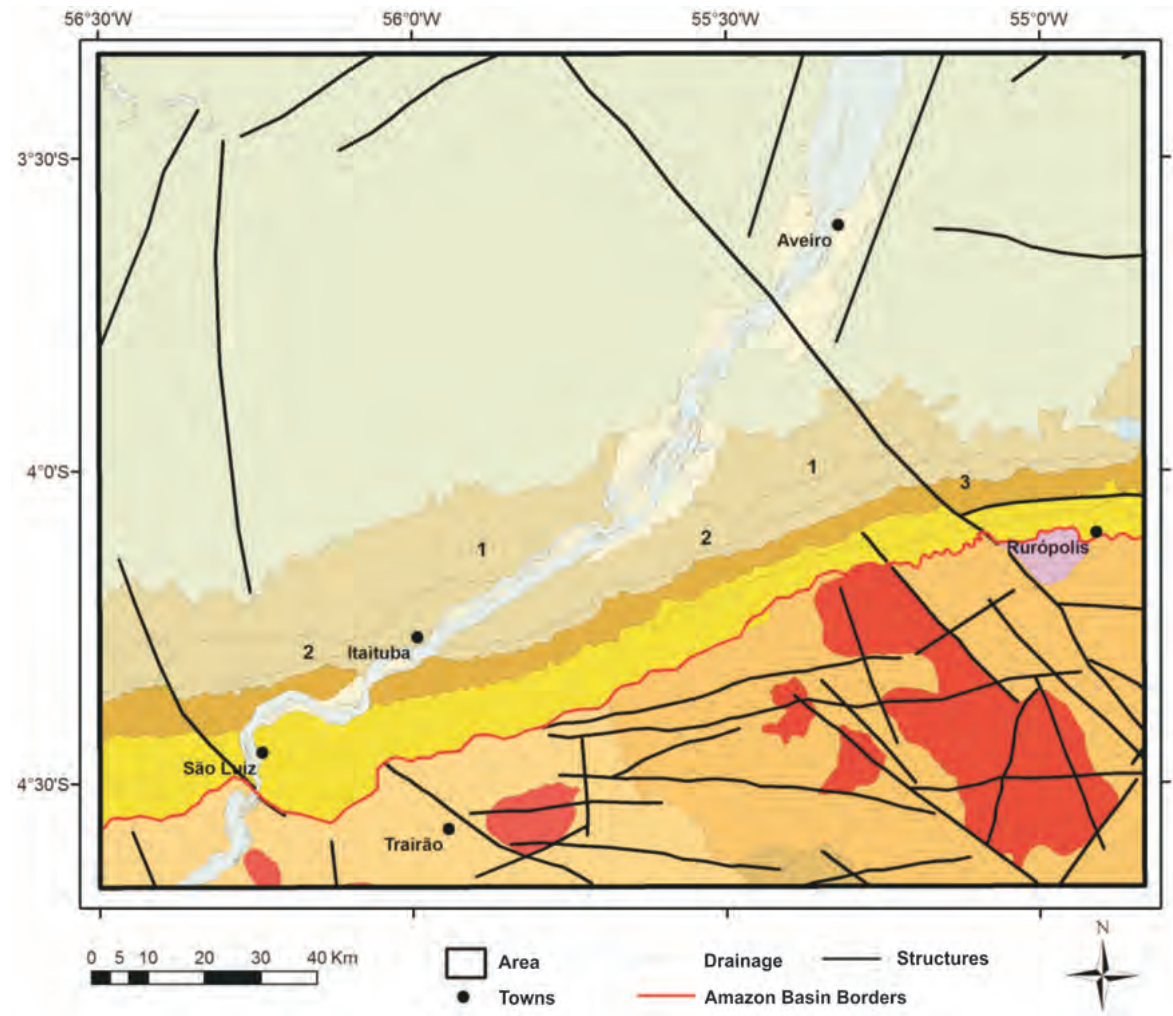

Legenda

Cenozoic

Quaternary

Alluvium

Mesozoic

Cretaceous

Alter do Chão Formation

Jurassic

Penatecaua Diabase

Paleozoic

Carboniferous

1 Nova Olinda Formation

2 Itaituba Formation

3 Monte Alegre Formation

Devonian

Curuá Group

Ererê Formation

Maecuru Formation

Proterozoic

Iriri Group

Salustiano Formation

Buiuçu Formation

Undifferentiated Type I Granites

Undifferentiated Type A Granites

Maloquinha Intrusive Suite

Figure 5 - Geologic map of the studied area (CPRM, 2008). Tapajós River (blue), structures (black) and basement/basin contact (red). 
Deposition of a thick sedimentary section took place in the basin after a small regressive pulse; its registry is represented by rocks of the Curuá Group, which in the studied area, is made up of Barreirinha and Curiri formations. Barreirinha Formation is made up of dark gray to black shales deposited during the global transgression in the Upper Devonian; diamictites, shales and marine siltites constitute the Curiri Formation (Cunha et al., 1994). Chitinozoans, acritarches, conodonts and tasmanites are abundant in the Barreirinha Formation's pyrite-rich black shales; the fossil assemblage is not abundant in the Curiri Formation's base, it is represented by rare chitinozoans (RADAMBRASIL, 1975).

Significant climatic changes from cold to hot and arid, between the Late Carboniferous and Late Permian, affected the basin, causing a transgressive-regressive depositional cycle, represented by rocks of the Tapajós Group. The cycle began with deposition of cross-bedded eolian sandstones, intercalated by siltites and shales from lakes and interdunes associated in the Monte Alegre Formation. Towards the top, in gradational contact, there was the deposition of infratidal limestones and sabkha plains' evaporites belonging to the Itaituba and Nova Olinda formations (Cunha et al., 1994). As a consequence of the size of the basin, its narrow connection with the sea and the small tide amplitudes, the carbonate sedimentation is represented by a restricted number of textural types characteristic of low energy such as calcarenites with bioclastic or calcisiltitic matrix, biocalcisiltites and micrites (Carozzi et al., 1973). After the detailed study of 2,500 thin sections, the authors established twenty microfacies differentiated into four different environments: infratidal, low- intertidal, high- intertidal and supratidal.

On top of the Nova Olinda Formation it was identified, based on evidences of microfauna composed by fusulinids and conodonts and in seismic session, an unconformity with approximately $21 \mathrm{Ma}$, marked by the presence of conglomerates with signs of subaerial exposure, besides halite with anhydritic and calciferous bands, nodular anhydrite with argillaceous matrix (chicken wire) and brown-reddish shales intercalated with intraformational conglomerates (Matsuda et al., 2004).

In the Amazon Basin, the Mesozoic tectonics begins with the uplifting caused by the mantle's thermal activation and a E-W distention, accompanied by an extensive Jura-Triassic basic tholeiitic magmatism (Penatecaua Diabase). This magmatism is marked $\mathrm{E}-\mathrm{W}$ sills and diabase dikes, in general NE-SW, that intruded the Paleozoic formations. The diabase bodies reach a thickness of about $900 \mathrm{~m}$ in the basin's central portion, they become thinner towards the basin's borders and disappear in the structural arches. This thickness variation is due to magma migration by gravity towards the basin's depocenter and erosion of the pre-Silurian formations in the arches (Wanderley Filho, 1991).

The main structures that affect the area are well marked NW lineaments/faults, which correspond to transcurrent faults with dextral kinematics (Rezende \& Brito, 1973) and transfer faults (Wanderley Filho, 1991). These authors determined preferential NW directions for the basement and NE for the Amazon Basin.

A system of transcurrent faults that crosses the basin and the northern portion of the studied area, with NW direction, was denominated by Costa (2002) as the Urucará System of Transcurrent Faults and it may correspond to the basement's shear zones. According to the same author, that system displaces the gravimetric axis of the basin, suggesting a sinistral movement.

Santos (2010), when carrying out structural studies from the analysis of linear features interpreted in the SRTM images, magnetometry and field data, observed lineaments that suggest the presence of important faults presenting the same N50-70W, N60$70 \mathrm{E}$ and $\mathrm{E}-\mathrm{W}$ main directions of the regional structures. According to Santos (2010), the NE and NW directions follow the big structures proposed by several authors for the Amazon Basin and basement. On the other hand, few papers (Costa, 1995) mention the $\mathrm{E}-\mathrm{W}$ faults in the Amazon Basin.

The Alter do Chão Formation, formalized by Caputo et al. (1971), is made up of a thick package of sandstones intercalated by pelite layers and, in a smaller scale, conglomerates. The sandstones are cross-bedded, fine- to medium-grained, brownreddish and variegated, argillaceous, kaolinic. Pelites, represented by varied proportions of siltites and argillites, are red and variegated, massive or laminated (Caputo et al., 1971). This unit's depositional environment is high-energy fluvial/lacustrinedeltaic.

\section{RESULTS AND DISCUSSION Synthetic data}

The magnetic anomalies generated in the geomagnetic context of the studied area can be seen in Figure 3, where the anomaly intensities decrease with the increment of the models' depths.

Figures 6 and 7 show enhancement maps generated from the geometric (Table 1) and magnetic (Table 2) parameters of the prisms in the studied area ( $A 1$ to $F 1$ ), data reduced to the pole (A2 to F2) and data at the pole (A3 to F3).

Visual analysis of the maps helped raise some considerations for each method. Anomalies of the magnetic field of the area under study, reduced to the pole and at the pole (A1, A2 and A3, in Fig. 6, respectively) show amplitude attenuations, correspond- 

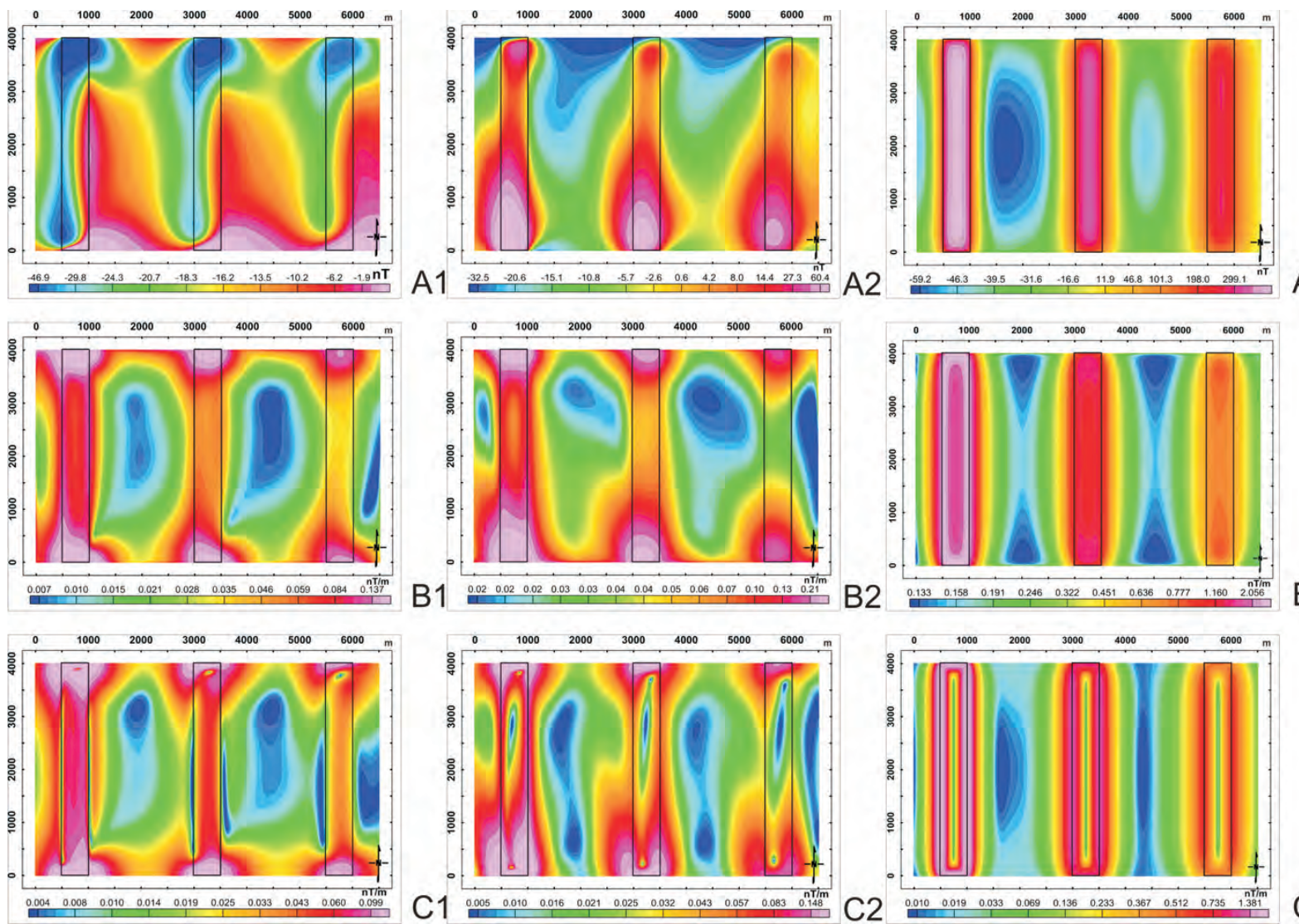

Figure 6 - Maps of the anomalous magnetic field (A1), RTP (A2) and at the pole (A3); the analytic signal amplitude (ASA-B1, ASA-RTP-B2 and ASA at the pole-B3) and the total horizontal gradient (THDR-C1, THDR-RTP-C2 and THDR at the pole-C3).

ing to an increase of the prisms' depths. The anomaly map of the studied area (A1, Fig. 6) shows that the borders of the models are delineated by minima and maxima, reflecting the dipolar character of the magnetic field. When applying the RTP filter to previous data it is verified that maxima are located approximately on top of the sources (A2, Fig. 6), similar to the anomalies located at the pole (A3, Fig. 6).

According to the analytic signal amplitude theory (ASA, Nabighian, 1972, 1974 and Roest et al., 1992), maps B1, B2 and B3 (Fig. 6) clearly define the borders and axes of thick bodies through relative maxima and minima, respectively. However, the signals are attenuated with the source depths. On the other hand, the most important characteristic, in this case, is the apparent independence of the inclination, since maps B1 and B2 (Fig. 6) present similar results, even if, recently, the analyticl signal amplitude (ASA) has been considered as dependent on the magnetic latitude for 3-D models (Li, 2006).

The behavior of the signals in the total horizontal derivative map (THDR, C1, Fig. 6), shows that this method depends on the magnetic inclination, while maps C2 and C3 (Fig. 6) reveal that the borders of the bodies are delineated by maxima, while the centers are indicated by minima (Cordell \& Grauch, 1985), which also are attenuated as a function of models' depth.

The analytic signal inclination (TDR) procedure, introduced by Miller \& Singh (1994) and tested in gravimetric data, has as its main characteristic to equalize the maximum amplitudes, making it independent from the source depths, and positioning them directly over their centers. This last attribute, however, shows that TDR is not a method for detecting the borders, as mentioned by Cooper \& Cowan (2008). According to Figure 1, TDR normalizes the first vertical derivative by the TDR. Due to the trigonometric characteristics of the tangential arc, TDR varies from $-\pi / 2$ to $+\pi / 2$. The D1 map (Fig. 7) shows that TDR depends on the magnetic inclination (e.g. Verduzco et al., 2004), while the D2 and D3 maps (Fig. 7) reflect the TDR mentioned attributes.

The total horizontal derivative of the tilt angle (TDR_THDR) technique, proposed by Verduzco et al. (2004), is independent of the magnetic inclination and intensity, besides enhancing and 

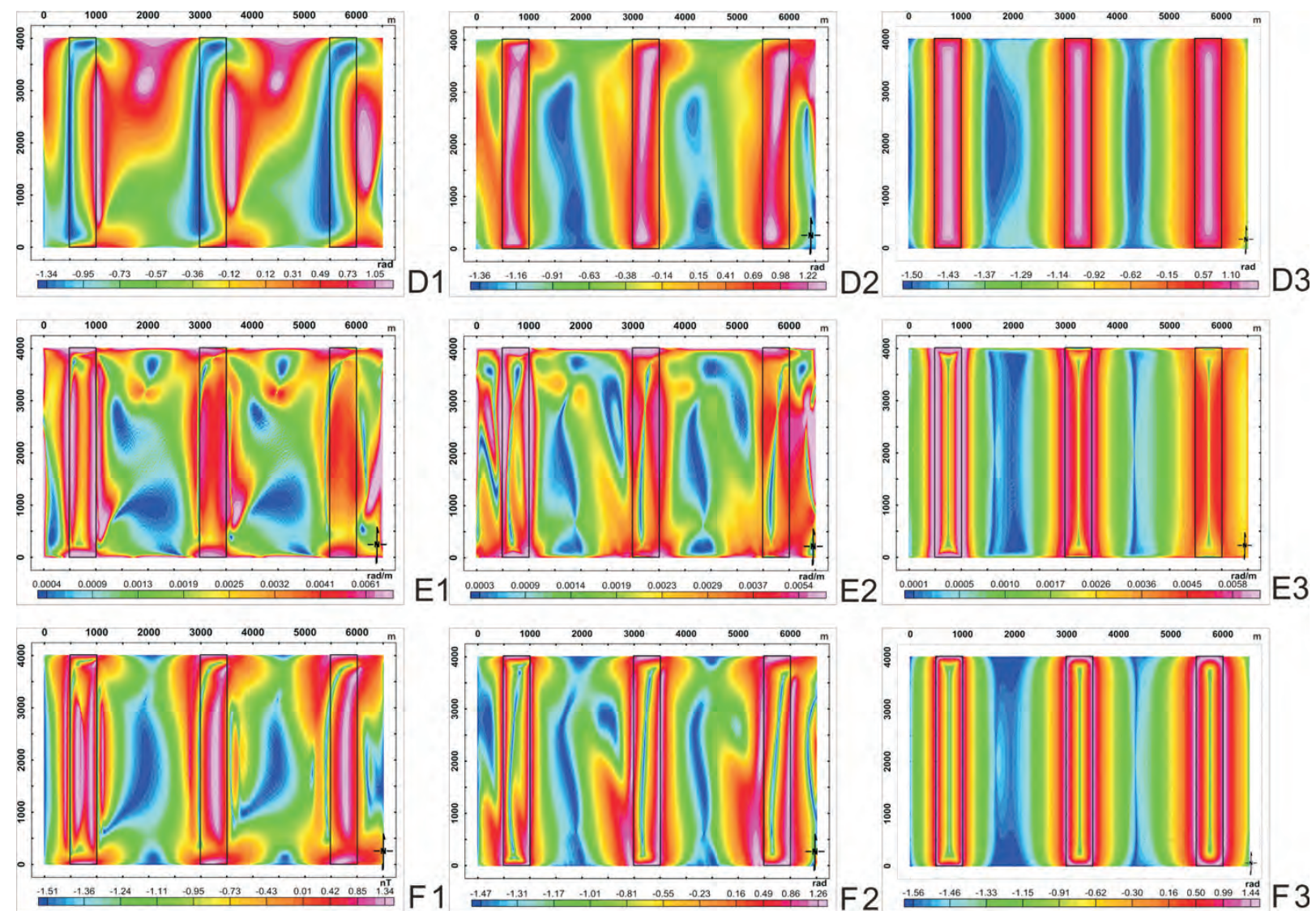

E1
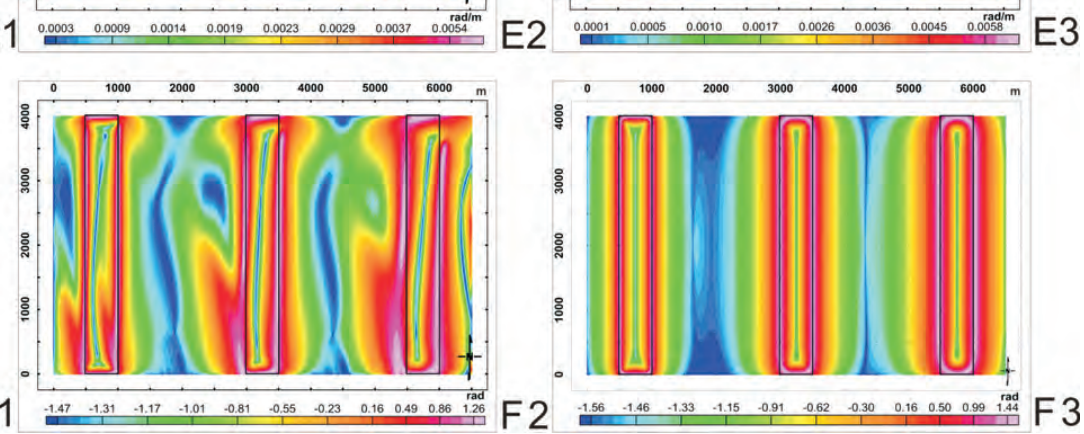

Figure 7 - Maps of the tilt angle (TDR-D1, TDR-RTP-D2 and TDR at the pole-D3); total horizontal derivative of the tilt angle (TDR_THDR-E1, TDR_THDR-RTP-E2 and TDR_THDR at the pole-E3), and tilt angle of the total horizontal derivative (TAHG-F1, TAHG-RTP-F2, and TAHG at the pole-F3).

centralizing the maximum amplitudes over the source limits. Such attributes are of the highest relevance for the qualitative interpretation of potential field data. However, when observing maps E1, E2 and E3 (Fig. 7), it is also noted that the anomaly amplitudes are attenuated with the models' depths, besides the profusion of noises (E1 and E2) (e.g. Ferreira et al., 2010), hindering the structural interpretation.

The TAHG method (Ferreira et al., 2010), while dependent on the magnetic latitude (F1, Fig. 7), presented satisfactory results only when applied to data reduced to the pole (F2, Fig. 7), once the borders of the prisms are equally enhanced by the maximum signal amplitudes, as a consequence of the ISA equalization and therefore without maintaining a relationship with the models' depth (Ferreira et al., 2010), in a similar way to map F3 (Fig. 7). Such results are presented as linear and continuous features over the sources, best reflecting the geologic structures and facilitating the qualitative interpretation (Ferreira et al., 2010).

In Figure 8 the power spectrum generated from synthetic data is represented, where the depths are statistically estimated in func- tion of the wave number. The results obtained show deep sources on the order of $300 \mathrm{~m}$; intermediate sources with estimated depths of $200 \mathrm{~m}$, and shallow sources with depths less than $200 \mathrm{~m}$, therefore in consonance with the real depths of the synthetic models.

\section{Real data}

In this part of the study the application of anomaly enhancement techniques to aeromagnetic data situated in low latitudes is demonstrated, reduced to the pole, within the Amazon Basin context and its exposed basement, with the objective of delineating the magnetic framework and comparing it with the already determined main lineaments and geologic structures in the studied area.

The aeromagnetic data used for this study belong to the Santarém Project (Eastern Area-4029), furnished by Petrobras, with a regular grid of $1,000 \times 1,000 \mathrm{~m}$, continuous for a height of about $1,000 \mathrm{~m}$, already corrected for the diurnal variation, subtracted from the IGRF and microleveled. Such data was collected in 1981 along lines spaced around every $3,000 \mathrm{~m}$, at a height of $1,000 \mathrm{~m}$ and following the N-S direction (CPRM, 2004). 

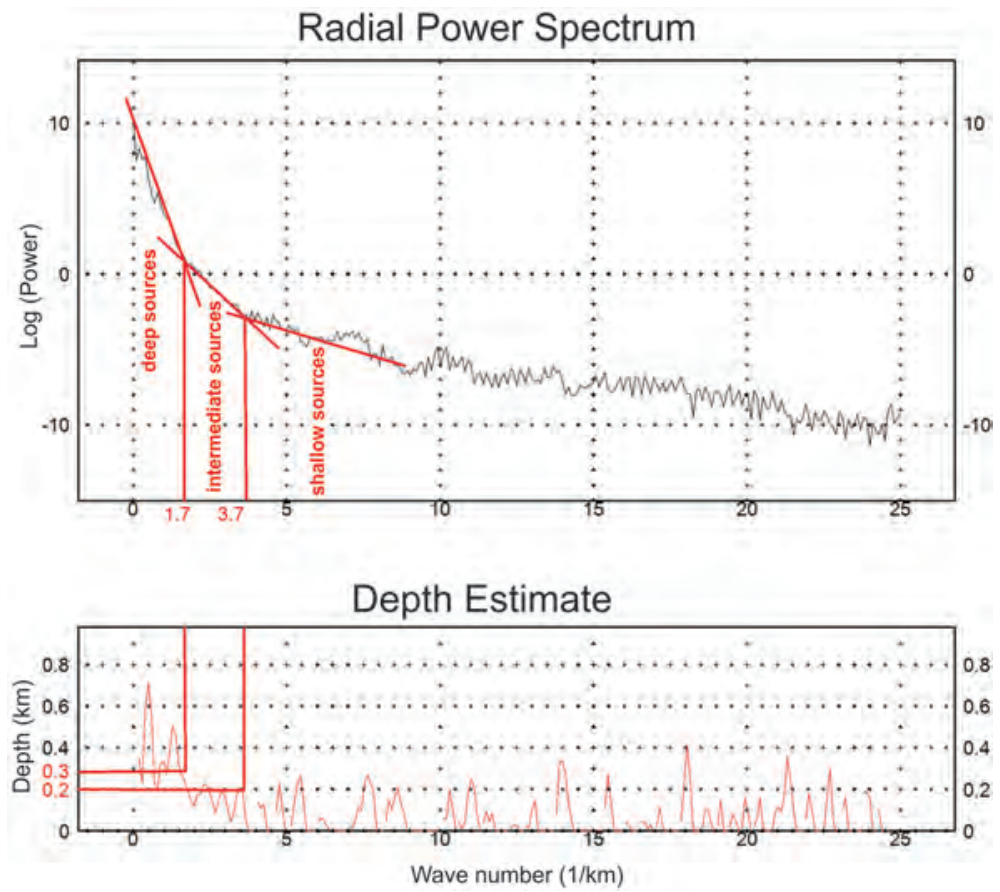

Figure 8 - Radial power spectrum generated from magnetic anomalies of the prisms (Fig. 3).
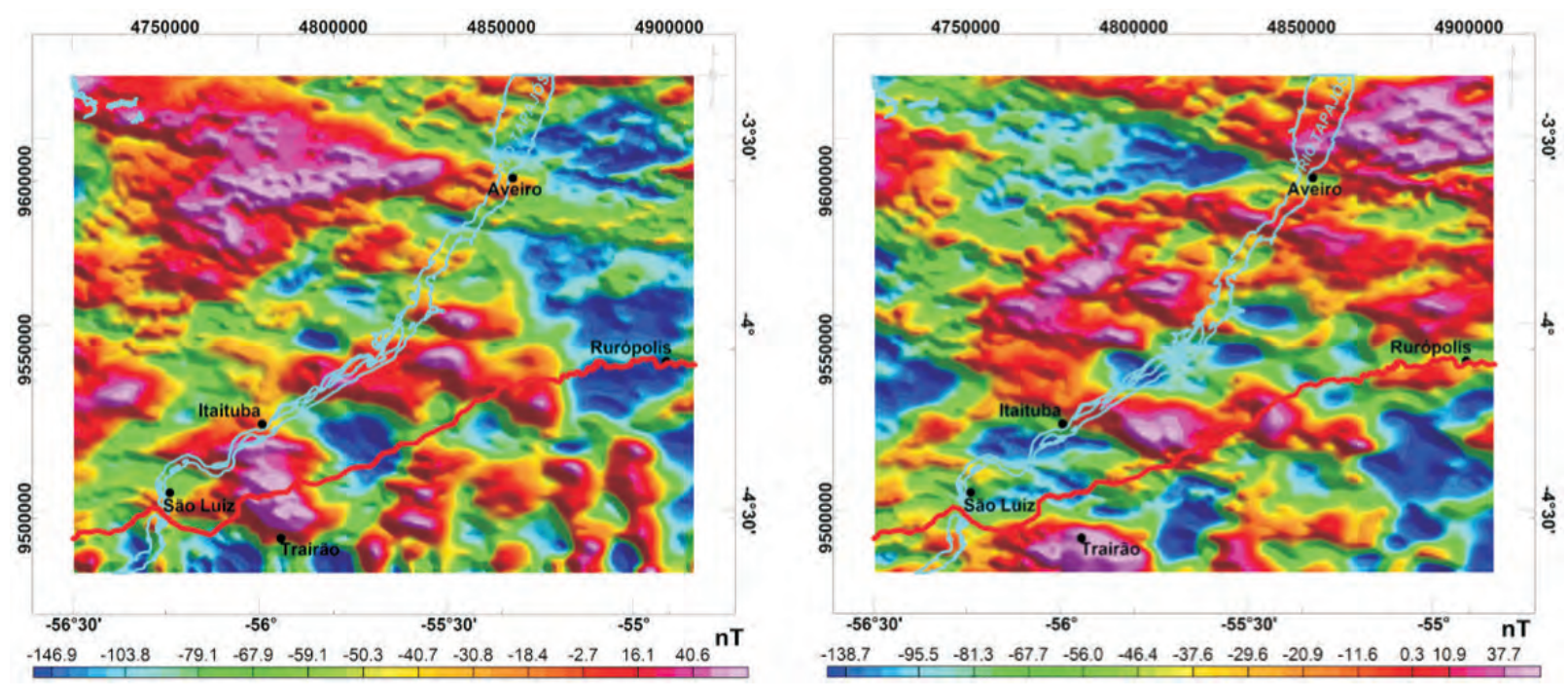

Figure 9 - Anomalous magnetic map of the studied area (left) and reduced to the pole (right). Tapajós River (blue) and basement/basin contact (red).

Figure 9 exhibits the anomalous magnetic map (left panel) and reduced to the pole (right panel).

Initially, data reduced to the pole was applied in upward continuation with the intention to visualize the deepest structures and attenuate the noises. In Figure 10 the digital elevation model (DEM) is displayed from top to bottom and built based on data furnished by the SRTM satellite, the anomalous magnetic map $(1,000 \mathrm{~m})$ and the upward continuation maps $(2,000$ and $5,000 \mathrm{~m}$ ). The parameters used for applying the RTP technique are shown in Table 2.

Using the continuation data (RTP) for 2,000 m (Fig. 11A) the enhancement methods that use the first order derivatives were applied, shown in Figure 1, results of which can be seen in Figure $11(B, C$ and $D)$. For the enhancement methods that make 
use of second order derivatives (Fig. 1), the option was to use the continuation data (RTP) for 5,000 meters, aiming to attenuate the noises and verify the persistence of the structures in depth (Fig. 11, E and F).

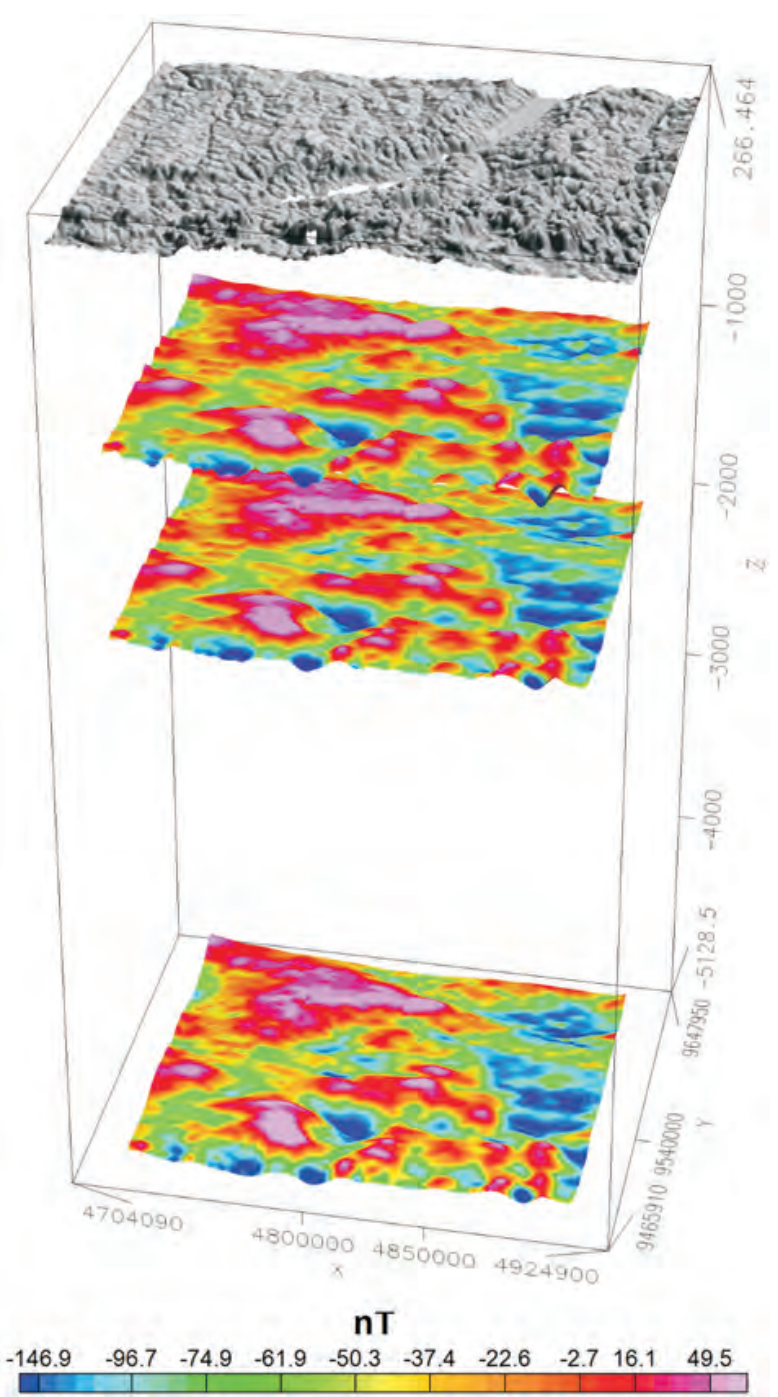

Figure 10 - Maps in 3-D perspective (from top to bottom): digital elevation model (DEM); anomalous magnetic map (1,000 m); continuation magnetic map for 2,000 m; continuation magnetic map for $5,000 \mathrm{~m}$.

The ASA response (Fig. 11B) exhibits lineaments with preferential NW-SE and WNW-ESE directions, in the basement context, which penetrate the basin, besides NE-SW structures in the Amazon Basin, represented by bell-shaped anomalies, characteristic of this method. In Figure 11C, the GHT emphasizes anomalies representative of the borders of long lineaments shown in ASA (Fig. 11B).

The TDR map (Fig. 11D) emphasizes trending tendencies, mainly the NW-SE and WNW-ESE directions, persistent in the basin, and it is possible to clearly observe these directions mainly in the northern portion of the area. This map, in the same way as the synthetic models, exhibits more clearly the structures due to the attribute of equalizing the signals from sources located at different depths.

Figures $11 \mathrm{E}$ and $11 \mathrm{~F}$ exhibit the results of the application of methods that involve second order derivatives, respectively TDR_THDR and TAHG. The TDR_THDR method, in spite of its advantages, already commented herein, did not present a satisfactory response. As a contrast, the TAHG technique evidenced more clearly NW-SE and NE-SW tendencies, facilitating the qualitative interpretation.

The magnetic-structural framework, resulting from the integration of the magnetic lineaments, is shown in Figure 12, trending mainly to NW-SE and WNW-ESE, corresponding to basement structures that penetrate the Amazon Basin, besides NE-SW subordinate trends. The same Figure shows overlapped structures defined by the RADAMBRASIL (1975), Wanderley Filho (1991) and CPRM (2008), for comparison effect. In addition, in Figure 12 a concordant pattern of the NW-SE and WNW-ESE trends is noticed, with the Faro-Juriti lineaments (NW-SE) standing out, which in the magnetometry is segmented by NE-SW structures (more recent or reactivated), and Tapajós (NE-SW).

Figure 13 was prepared to compare the magnetic tendencies of Figure 12 with the surface lineaments obtained through the interpretation of the digital elevation models (SRTM) accomplished by Santos (2010), where a good correspondence of the structural patterns is observed.

In this work, estimates of the sources' depths were also accomplished, through the radial power spectrum method (Fig. 14), generated from the original data $(1,000 \mathrm{~m})$, with deep and intermediate sources, depths on the order of $8 \mathrm{~km}$ and between 8 and $4 \mathrm{~km}$, representative of the basement, and shallow sources with depths of less than $4 \mathrm{~km}$, linked to the Amazon Basin.

\section{CONCLUSIONS}

In summary, the responses given by the synthetic models showed that, for the geomagnetic environment of the studied area, the reduction to the pole (RTP) technique made possible that the anomalies be positioned near the sources, minimizing the effects of the magnetic inclination, in spite of the discrepancies when compared to data at the pole. The several enhancement techniques applied to real data reduced to the pole were considered effective, in areas of low magnetic latitudes, for the structural-magnetic outline, with emphasis for the TAHG method. 

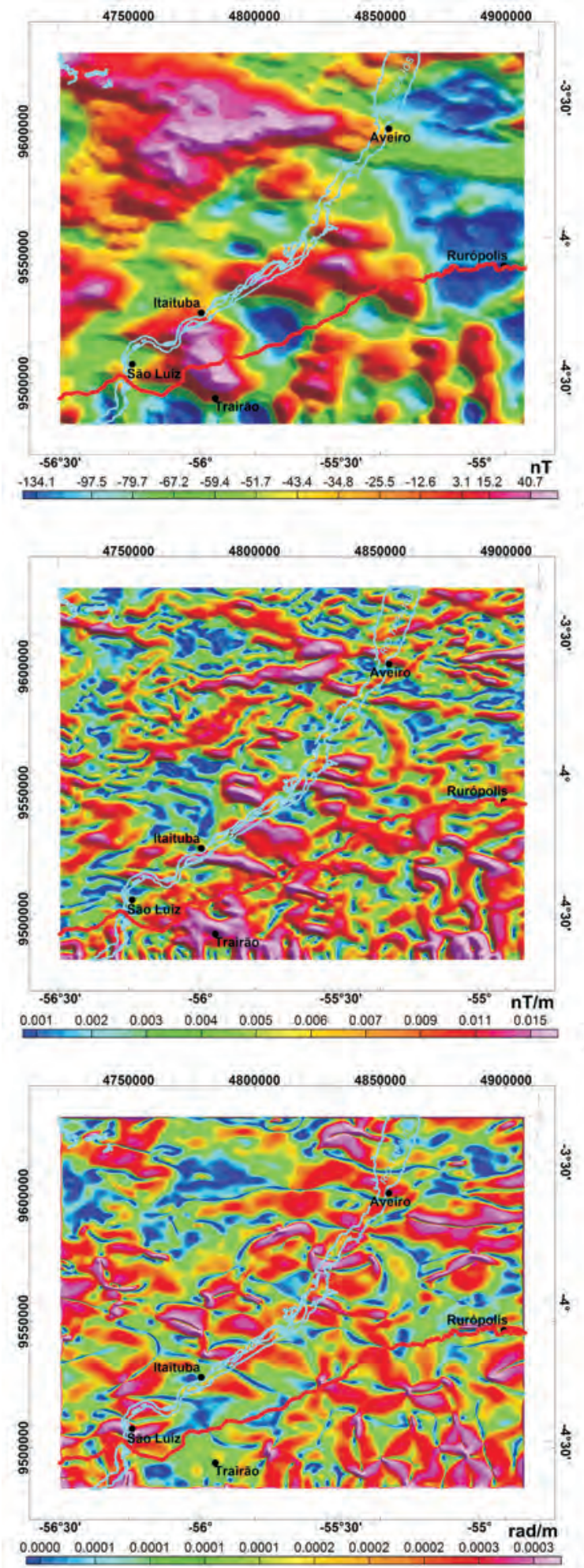
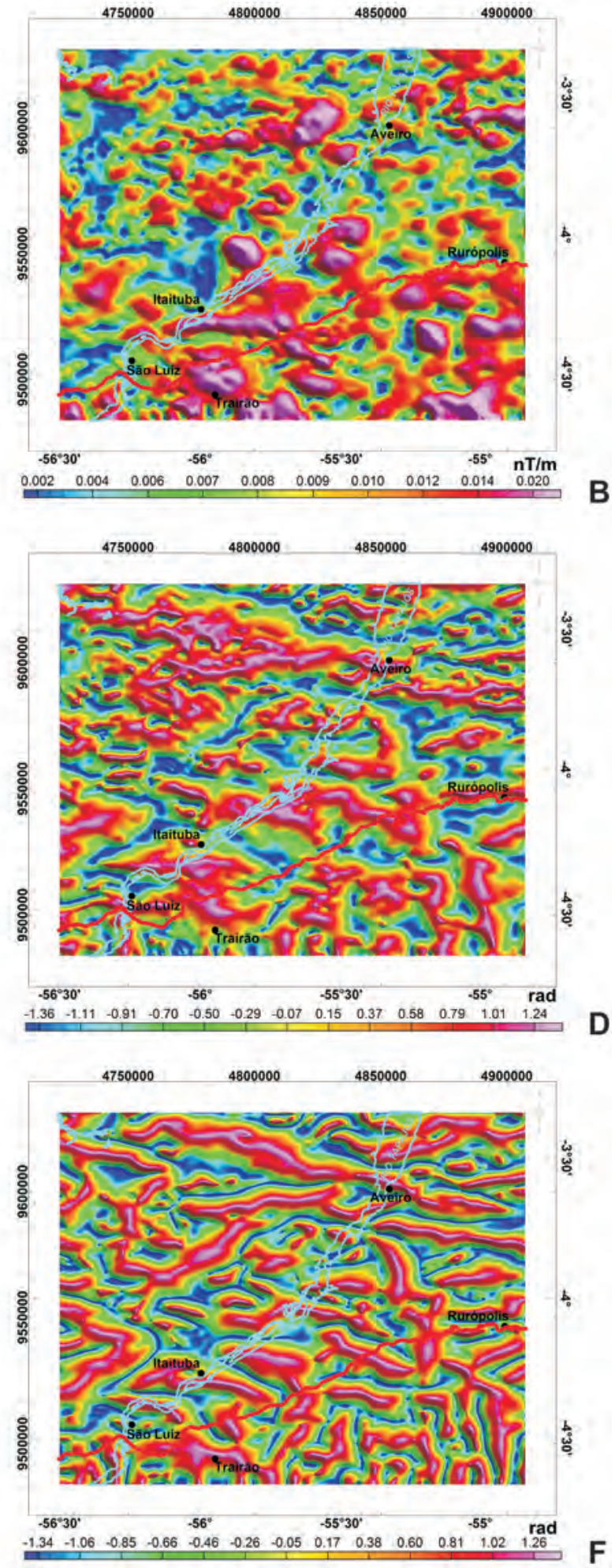

Figure 11 - Derivative maps, after applying enhancement methods: magnetic anomaly map $(2,000 \mathrm{~m})$ reduced to the pole (A), map of the analytic signal amplitude (ASA-2,000 m, B), map of the total horizontal derivative (THDR-2,000 m, C), map of the tilt angle (TDR-2,000 m, D), map of the total horizontal derivative of the tilt angle (TDR_THDR-5,000 m, E) and map of the tilt angle of the total horizontal derivative (TAHG-5,000 m, F). Tapajós River (blue) and basement/basin contact (red). 


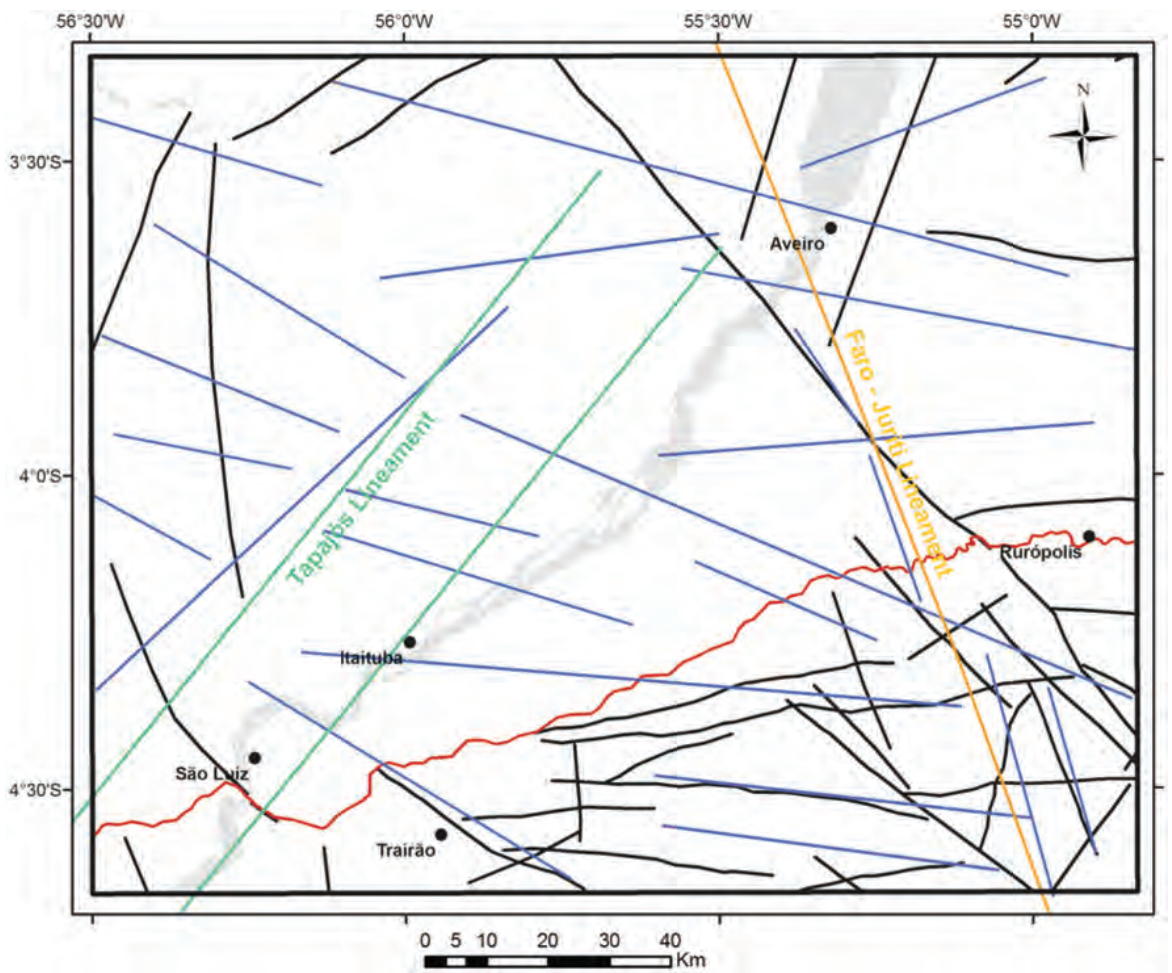

Figure 12 - Magnetic lineaments map (blue) indicating structures defined by several authors (RADAMBRASIL, 1975 green; Wanderley Filho, 1991 - orange; CPRM, 2008 - black). Tapajós River (blue) and basement/basin contact (red).

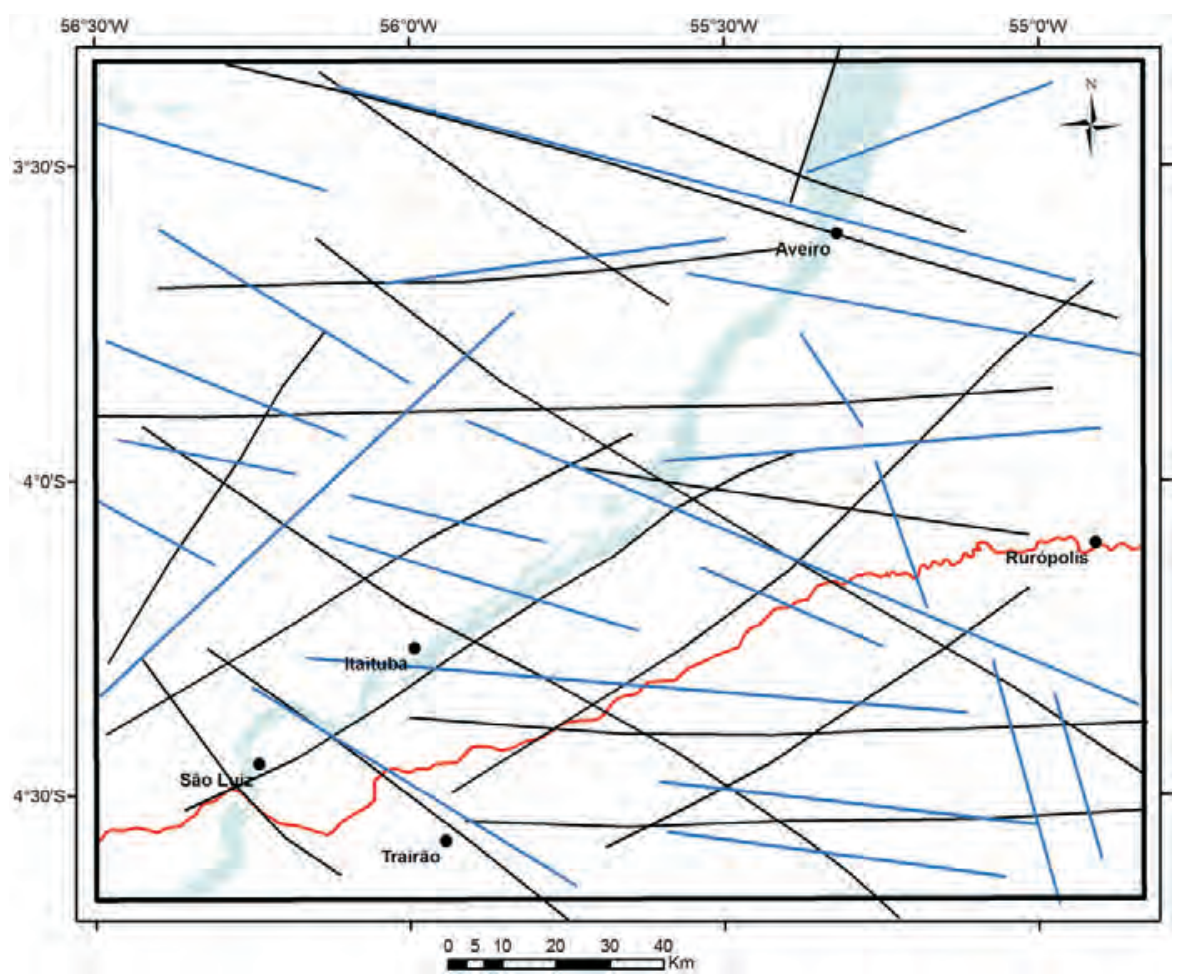

Figure 13 - Magnetic lineaments (blue) and surface map (black, according to Santos, 2010). Tapajós River (blue) and basement/basin contact (red) 


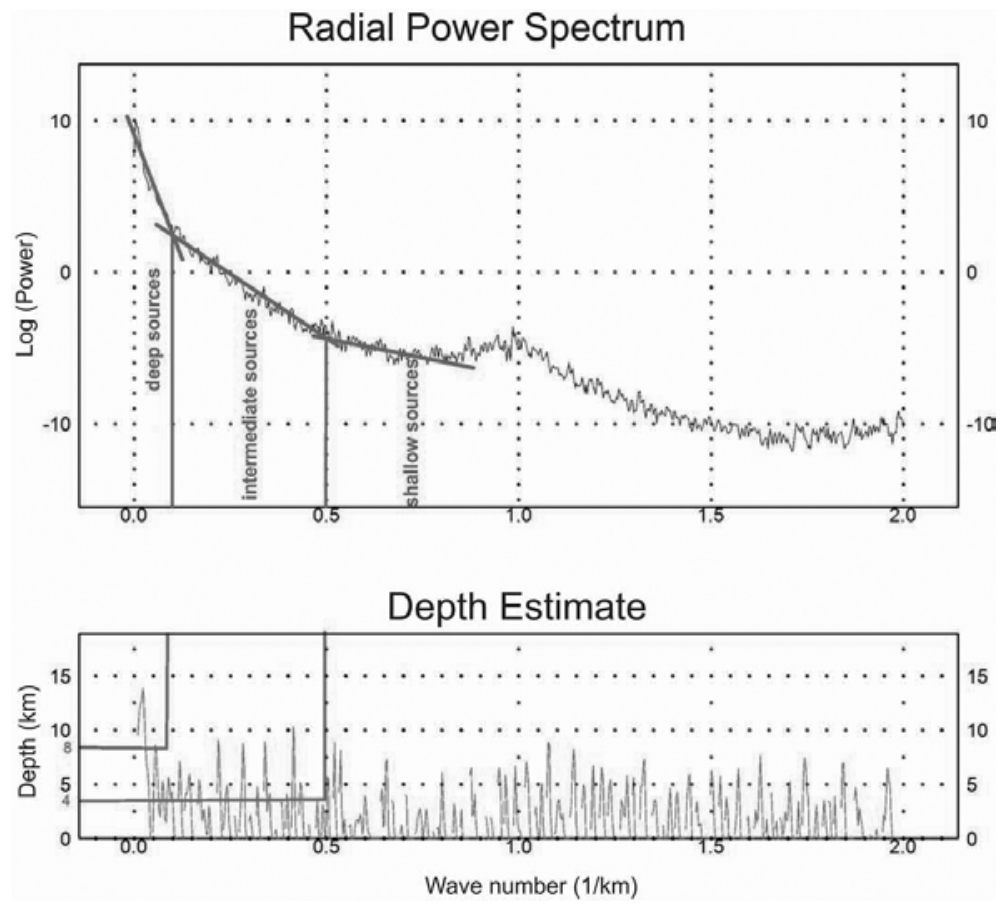

Figure 14 - Radial power spectrum from the area under study.

Finally, it is noticed that the tendencies delineated from the magnetic maps derived from the application of the enhancement techniques are concordant with the structures interpreted through traditional geologic methods.

\section{ACKNOWLEDGEMENTS}

The authors express their appreciation to Petróleo Brasileiro S.A. (Petrobras) for financing the research and Comissão de Aperfeiçoamento de Pessoal de Ensino Superior (CAPES) for the Doctorate Scholarship (ABSB). F.J.F. Ferreira acknowledges Conselho Nacional de Desenvolvimento Científico e Tecnológico (CNPq) for the Productivity Scholarship in Research.

\section{REFERENCES}

BAHIA RBC \& QUADROS MLES (Org.). 2000. Geologia e recursos minerais da Folha Caracol SB.21-X-C. Estados do Pará e Amazonas. Escala 1:250.000. Brasília: CPRM, 1 CD-ROM. Programa de Levantamentos Geológicos Básicos do Brasil (PLGB). Projeto Especial Província Mineral do Tapajós (Promin Tapajós).

BHASKARA RAO D \& RAMESH BABU N. 1991. A rapid method for three-dimensional modeling of magnetic anomalies. Geophysics, 56(11): 1729-1737.

BHATTACHARYYA BK. 1964. Magnetic anomalies due to prism-shaped bodies with arbitrary polarization. Geophysics, 29(4): 517-531.
BLAKELY RJ. 1996. Potential Theory in Gravity \& Magnetic Application: Cambridge University Press. $441 \mathrm{p}$.

BONGIOLO ABS, DE SOUZA J, FERREIRA FJF \& DE CASTRO LG. GRAV_MAG_PRISMA: Um programa em MATLAB ${ }^{\circledR} /$ OCTAVE para geração de anomalias gravimétricas e magnéticas de corpos prismáticos. Revista Brasileira de Geofísica (subject).

BRIGGS IC. 1974. Machine contouring using minimum curvature. Geophysics, 39(1): 39-48.

BRITO MFL. 2000. Suíte Intrusiva Parauari. In: ALMEIDA ME, BRITO MFL, FERREIRA AL \& MONTEIRO AS. (Org.). Geologia e recursos minerais da Folha Vila Mamãe Anã (SB.21-V-D); Estados do Pará e Amazonas. Escala 1:250.000. Nota explicativa. Brasília: CPRM, 1 CD-ROM. Projeto Especial Província Mineral do Tapajós (Promin Tapajós).

CAPUTO MV, RODRIGUES R \& VASCONCELOS DNN. 1971. Litoestratigrafia da Bacia do Amazonas. RENOR - Petrobras, 92 p. (Relatório interno).

CAROZZI AV, PAMPLONA HRP, CASTRO JC \& CONTRONEIRAS CJA. 1973. Ambientes deposicionais e evolução tecto-sedimentar da seção clástica paleozóica da bacia do médio Amazonas. In: Congresso Brasileiro de Geologia, 27, Anais, p. 279.

COOPER GRJ \& COWAN DR. 2008. Edge enhancement of potential-field data using normalized statistics. Geophysics, 73(3): H1-H4.

CORDELL L \& GRAUCH VJS. 1985. Mapping basement magnetization zones from aeromagnetic data in the San Juan Basin, New Mexico. The 
Utility of Regional Gravity and Magnetic Anomalies Maps. Society of Exploration Geophysicists, p. 181-197.

COOPER GRJ \& COWAN DR. 2006. Enhancing potential field data using filters based on the local phase. Computers \& Geosciences, 32(10): 1585-1591.

COSTA ARA. 1995. Bacia do Amazonas, sobre os trends estruturais cretáceos e as possibilidades de existência de acumulações comerciais de petróleo em armadilhas paleozoicas. Belém, Petrobras, Relatório Técnico, 17 p. (inédito).

COSTA ARA. 2002. Tectônica Cenozóica e Movimentação Salífera na Bacia do Amazonas e suas Relações com a Geodinâmica das Placas da América do Sul, Caribe, Cocos e Nazca. Master dissertation, Universidade Federal do Pará - UFPA, Belém, 237 p.

CPRM - Serviço Geológico do Brasil. 2004. Projeto Aerogeofísico Santarém (Área Leste): relatório final do levantamento e processamento dos dados magnetométricos e gamaespectrométricos. Texto técnico. Rio de Janeiro: PROSPEC S.A. - Geologia, Prospecções e Aerofotogrametria, v.1. 51 p. il. anexos + mapas. Programa Geologia do Brasil (PGB).

CPRM - Serviço Geológico do Brasil. 2008. Programa Geologia do Brasil. Mapas geológicos estaduais escala 1:1.000.000. Geologia e recursos minerais do Estado do Pará.

CUNHA PRC, GONZAGA FG, COUTINHO LFC \& FEIJÓ FJ. 1994. Bacia do Amazonas. Boletim de Geociências da Petrobras, 8(1): 47-67

FARACO MTL, CARVALHO JM DE A \& KLEIN EL. 2004a. In: SCHOBBENHAUS C et al. (Ed.). Carta geológica do Brasil ao milionésimo: Sistema de Informações Geográficas - SIG. Programa Geologia do Brasil. Folha SC.22 - Tocantins. Brasília: CPRM, 1 CD-ROM.

FARACO MTL, CARVALHO JM DE A \& KLEIN EL. 2004b. In: SCHOBBENHAUS C et al. (Ed.). Carta geológica do Brasil ao milionésimo: Sistema de informações geográficas - SIG. Programa Geologia do Brasil. Folha SB.22 - Araguaia. Brasília: CPRM, 1 CD-ROM.

FERREIRA FJF, DE SOUZA J, BONGIOLO ABS, CASTRO LG de \& ROMEIRO MAT. 2010. Realce de anomalias magnéticas do gradiente horizontal total usando a inclinação do sinal analítico. Parte I - Aplicação a dados sintéticos. In: IV Simpósio Brasileiro de Geofísica. 1 CD-ROM, 2193. Brasília-DF.

GEOSOFT. 2001. Magmap - 2D Frequency Domain Processing. Geosoft Technical Note, $34 \mathrm{p}$.

LI X. 2006. Understanding 3-D analytic signal amplitude. Geophysics, 71(2): L13-L16.

LI X. 2008. Magnetic reduction-to-the-pole at low latitudes: Observations and considerations. The Leading Edge, 27(8): 990-1002.

MATSUDA NS, DINO R \& WANDERLEY FILHO JQ. 2004. Revisão litoestratigráfica do Grupo Tapajós, Carbonífero Médio-Permiano da Bacia do Amazonas. Boletim de Geociências da Petrobras, 12: 435-441.
MILLER HG \& SINGH V. 1994. Potential field tilt - a new concept for Iocation of potential field sources. Journal of Applied Geophysics, 32(2-3): 213-217.

NABIGHIAN MN. 1972. The analytic signal of two-dimensional magnetic bodies with polygonal cross-section: Its properties and use for automated anomaly interpretation. Geophysics, 37(3): 507-517.

NABIGHIAN MN. 1974. Additional comments on the analytic signal of two-dimensional magnetic bodies with polygonal cross-section. Geophysics, 39(1): 85-92.

PLOUFF D. 1976. Gravity and magnetic fields of polygonal prisms and application to magnetic terrain corrections. Geophysics, 41(4): 727741.

RADAMBRASIL. 1975. SANTOS DB, FERNANDES PECA, DREHER AM, CUNHA FMB, BASEI MAS \& TEIXEIRA JBG. In: BRASIL. Departamento Nacional da Produção Mineral. Projeto RADAMBRASIL; Folha SB.21 Tapajós. Rio de Janeiro. p. 409 (Levantamento de Recursos Naturais, 7).

REZENDE WM de \& BRITO CG de. 1973. Avaliação Geológica da Bacia Paleozóica do Amazonas. In: Congresso Brasileiro de Geologia, 27: 228-245.

RIZZOTTO GJ et al. 2004. In: SCHOBBENHAUS C et al. (Ed.) Carta geológica do Brasil ao milionésimo: Sistema de Informações Geográficas - SIG. Programa Geologia do Brasil. Folha SC.21-Juruena. Brasília: CPRM, 1 CD-ROM.

ROEST WR, VERHOEF J \& PILKINGTON M. 1992. Magnetic interpretation using the 3-D analytic signal. Geophysics, 57(1): 116-125.

SANTOS TBS. 2010. Análise Estrutural da Bacia do Amazonas, Região de Itaituba - PA. Master dissertation - Pós-Graduação em Geologia, Universidade Federal do Paraná (UFPR), Curitiba, 101 p.

SINGH B \& GUPTASARMA D. 2001. New method for fast computation of gravity and magnetic anomalies from arbitrary polyhedra. Geophysics, 66(2): 521-526.

SPECTOR A \& GRANT FS. 1970. Statistical models for interpreting magnetic data. Geophysics, 35(2): 293-302.

TALWANI M. 1965. Computation with the help of a digital computer of magnetic anomalies caused by bodies of arbitrary shape. Geophysics, 30(5): 797-817.

VASQUEZ ML, ROSA COSTA LT, SILVA CMG, RICCI PSF, BARBOSA JPO, KLEIN EL, LOPES ECS, MACAMBIRA EMB, CHAVES CL, CARVALHO JMA, OLIVEIRA JGF, ANJOS GC \& SILVA HR. 2000a. Descrição das unidades litoestratigráficas e litodêmicas. In: VASQUEZ ML \& KLEIN 
EL (Org.). Geologia e recursos minerais da Folha Rio Novo - SB.21-ZC: Estado do Pará. Escala 1:250.000. Brasília: CPRM, 1 CD-ROM. Programa de Levantamentos Geológicos Básicos do Brasil (PLGB). Projeto Especial Província Mineral do Tapajós (Promin Tapajós).

VASQUEZ ML, ROSA COSTA LT, SILVA CMG, RICCI PSF, BARBOSA JPO, KLEIN EL, LOPES ECS, MACAMBIRA EMB, CHAVES CL, CARVALHO JMA, OLIVEIRA JGF, ANJOS GC \& SILVA HR. 2000b. Descrição das unidades litoestratigráficas e litodêmicas. In: KLEIN EL \& VASQUEZ ML (Org.). Geologia e recursos minerais da Folha Vila Riozinho - SB.21Z-A: Estado do Pará. Escala 1:250.000. Brasília: CPRM, 1 CD-ROM. Programa Levantamentos Geológicos Básicos do Brasil (PLGB). Projeto Especial Província Mineral do Tapajós (Promin Tapajós).
VERDUZCO B, FAIRHEAD JD, GREEN CM \& MACKENZIE C. 2004. New insights into magnetic derivatives for structural mapping. The Leading Edge, 23(2): 116-119.

WANDERLEY FILHO JQ. 1991. Evolução Estrutural da Bacia do Amazonas e sua relação com o embasamento. Master dissertation, Universidade Federal do Pará (UFPR), 125 p.

WI JNSC, PEREZ C \& KOWALCZYK P. 2005. Theta map: Edge detection in magnetic data. Geophysics, 70 (4): L39-L43.

\section{NOTES ABOUT THE AUTHORS}

Alessandra de Barros e Silva Bongiolo graduate in Geology in (UFPR-2001), M.Sc. in Environmental Geology (UFPR-2007) and Ph.D. in Geology Exploration (UFPR-2011). Presently working as a consultant in the areas of mineral exploration and the environment.

Francisco José Fonseca Ferreira is Geologist (UFPE-1970), expert in Applied Geophysics (UFBA-1974), Master and Doctor degree in Science (USP-1982; USP-1991), with professional experience in CPRM (1972-1980) and IPT (1980-1990). Since 1998 coordinates the Laboratory for Research in Applied Geophysics - LPGA/UFPR, where develops multidisciplinary research applied in environment, mining and groundwater. Presently has a scholarship for Productivity in Research from CNPq (1D) and Associate Professor at Department of Geology (UFPR), where he teaches applied geophysics in classes of graduate and post-graduate. 